\title{
Properties of Cementitious Repair Materials for Concrete Pavement
}

\author{
Shih Horng Yeo $\mathbb{D},{ }^{1}$ Kim Hung Mo $\mathbb{D}^{1},{ }^{1}$ Md. Akter Hosen ${ }^{(D)},{ }^{2}$ and Hilmi Bin Mahmud ${ }^{1}$ \\ ${ }^{1}$ Department of Civil Engineering, Universiti Malaya, Kuala Lumpur 50603, Malaysia \\ ${ }^{2}$ Department of Civil and Environmental Engineering, College of Engineering, Dhofar University, Salalah, Oman \\ Correspondence should be addressed to Kim Hung Mo; khmo@um.edu.my
}

Received 7 September 2021; Revised 26 November 2021; Accepted 29 December 2021; Published 4 February 2022

Academic Editor: Francesco Colangelo

Copyright (C) 2022 Shih Horng Yeo et al. This is an open access article distributed under the Creative Commons Attribution License, which permits unrestricted use, distribution, and reproduction in any medium, provided the original work is properly cited.

\begin{abstract}
This review aims to provide an insight into concrete pavement repair materials by gathering the relevant research outcomes and specifications. It provides a systematic literature review that focuses on pavement repair and types of cementitious repair material. In general, conventional cementitious repair materials can be divided into 4 categories: ultra-rapid, rapid, accelerated, and normal strength gain. The mechanical and durability properties of conventional cementitious repair materials, i.e., calcium sulphoaluminate-based, calcium aluminate-based, polymer-modified concrete, and ordinary Portland cement-based repair materials are highlighted. The paper also discusses the newly developed ultra-high performance concrete and alkali-activated materials as potential repair materials for concrete pavement due to the good mechanical and durability performance. As a final point, this review may help readers to understand and determine the appropriate type of repair material when distress occurs in concrete pavement.
\end{abstract}

\section{Introduction}

According to Blanchard's American Highway Engineers' Handbook of 1919, the history of concrete pavement began in 1879 in Scotland [1]. Concrete pavement is commonly used in highways, airports, and bridge decks due to their ability to carry heavy loads and long-lasting performance. There are 7 types of concrete pavement widely constructed around the world, which include (1) jointed plain concrete pavement; (2) jointed reinforced concrete pavement; (3) continuously reinforced concrete pavement; (4) prestressed concrete pavement, (5) precast concrete pavement; (6) roller compacted concrete (RCC), pavement; and (7) pervious concrete pavement [2].

Concrete pavement is designed to have a longer life span with a lower frequency of future maintenance. A wellmaintained concrete pavement can last for more than 40 years [3]. It was reported that the first American concrete pavement built in 1891 remains in service [4]. Apart from being more durable, concrete pavement is preferred in certain situations such as laying directly over poor soils due to the uniform load distribution characteristic of the pavement $[5,6]$. As a result, most of the airports rely on concrete pavements to construct the taxiway, runway, and apron, especially where heavy aircraft is involved.

Today, concrete pavement is widely constructed around the world. In 2018, the United States (US) Federal Highway Administration recorded around $90,030 \mathrm{~km}$ of rural and urban concrete pavement [7], while the concrete pavement length in Japan is $55,218 \mathrm{~km}$ [8]. Germany has approximately $25 \%$ of its major roads made of concrete, while in Belgium around $17 \%$ of its overall road $(134,000 \mathrm{~km})$ is concrete pavement. In Austria, two-thirds of high-volume motorways of about $4,000 \mathrm{~km}$ are concrete pavements [9]. France has been using concrete pavements for a long time, and it has 600 lane $\mathrm{km}$ of continuously reinforced concrete pavement [10]. In South-East Asia, Thailand has constructed more than $5,624 \mathrm{~km}$ of concrete road [11].

The growth of the concrete pavement network has led to the increment of concrete repair works. To ensure the 
success of the repair jobs, material selection is crucial. The considerations include (1) material's strength (compressive strength, flexural strength, fatigue resistance, etc.); (2) volumetric stability (shrinkage and coefficient of thermal expansion); and (3) the ability to withstand environmental load (i.e. freeze-thaw attack, sulphate attack, de-icer chemical attack, etc.) [12]. Pavement repair materials made from magnesium phosphate, calcium aluminate cement, polymer-modified cementitious material, and high early strength cement can gain very high strength at an early age, therefore pavement can be put into service within hours (e.g., 3 hours) [13].

Newly developed materials such as ultra-high performance concrete (UHPC) and alkali-activated materials (AAM) have attracted much interest in the pavement repair industry. UHPC possesses superior mechanical properties such as compressive strength greater than $150 \mathrm{MPa}$ and a post-cracking tensile strength greater than $5 \mathrm{MPa}$ [14]. It is an effective repair material for bridge deck that is deteriorated by traffic load and freeze-thaw cycle [15]. AAM has gained popularity in the industry due to the reduction of carbon footprint. Unlike conventional AAM, recently developed AAM can gain strength without elevated temperature [16] and compressive strength as high as $145 \mathrm{MPa}$ [17]. AAM is considered durable; the chloride ingress is similar to concrete with a low water-to-cement ratio $(\mathrm{w} / \mathrm{c})$ and it is more superior to concrete in terms of chemical attack [18]. Hence, the potential usage of AAM as a pavement repair material is excellent.

Although concrete repair material technology has grown substantially to date, limited reviews have been done about the cementitious repair materials for concrete pavement. The main objective of this review is to provide an insight into the types of cementitious pavement repair materials used for repair in the industry, mostly for partial- and full-depth repairs.

\section{Pavement Distress}

Distresses in the pavement are developed gradually over time due to cumulative fatigue load from traffic and environmental effects [19]. When the pavement is unable to perform, it has to undergo a repair process. The term repair in this paper refers to the work to restore a damaged pavement to its original or as-built condition in terms of strength and/or capacity.

Cement Concrete and Aggregates Australia categorises pavement distresses into 3 types, which are structural distress, durability distress, and functional distress [13], whilst NCHRP Report 747 groups distress into functional and structural distresses; durability issue is considered as structural distress [20]. Structural distress is related to cracking, joint deterioration, and punch-out. Once these occur, the traffic carrying capacity of the pavement is affected. Functional distress, which includes surface defects, roughness, and noise, will affect the ride quality and safety of the pavement.

The typical repair techniques for damaged concrete pavement involve full depth repair (FDR), partial depth repair (PDR), and overlay [21]. As determined by the degree of damage, most of the functional distress and surface damage require PDR, overlay, and surface grinding. In the case of structural and durability distress, the recommended repair work is FDR or overlay. PDR is for rehabilitating shallow and localised surface defects, whereas FDR is conducted within the full depth of the pavement. This review focuses on the technology in cementitious material repair for PDR and FDR of concrete pavement.

\section{Repair Material Requirements}

Normally, a repair material is expected to last for 5-15 years [22]. The material must be compatible with the existing substrate to ensure that the material can function until the end of service life. Compatibility can be defined as a balance of physical, chemical, and electrochemical properties, as well as dimensions between repair material and the existing substrate. This is to ensure that the repair can withstand all the stresses induced by volume changes, chemical, and electrochemical effects without distress and deterioration over a designated period [23]. The general requirements of repair material to prevent property mismatch in the repair of structural concrete is shown in Table 1.

3.1. Strength. The mechanical properties of pavement repair materials are normally evaluated through their compressive strength or flexural strength. During repair, it is important to ensure that the repair material is not loaded prematurely; else it can have a detrimental effect on the long-term performance. Therefore, the repair material for pavement must meet certain strength criteria before opening to traffic.

3.1.1. PDR. For PDR, the material strength required to carry traffic is around $11 \mathrm{MPa}-13 \mathrm{MPa}$ [27]. The load-carrying mechanism of PDR is different from FDR where PDR only carries compressive stress and does not carry flexural stress or tensile stress. However, certain road authority requires the materials to carry flexural stress. The strength requirements for PDR are shown in Table 2.

3.1.2. FDR. The repair material for FDR is required to carry both compression and tension stresses. Hence, the strength required for open-to-traffic is much higher than that for PDR. In the US, the minimum opening strength varies with repair size, typically ranging from $13.8 \mathrm{MPa}$ to $20.7 \mathrm{MPa}$ (Table 3). In contrast, the United Kingdom highway authority has regulated the open-to-traffic strength to be $25 \mathrm{MPa}$ regardless of the size [29]. Recent literature by Louisiana Transportation Research Center suggests that the strength can be reduced from 20.7 MPa to $13.8 \mathrm{MPa}$ [30].

3.2. Volumetric Stability. Normally shrinkage occurs at different ages in the life of the material; concrete starts to shrink when the hydration process begins, and it can last for years. There are several types of shrinkage to be considered in cementitious repair materials, including autogenous 
TABLE 1: General requirement for repair material [24-26].

\begin{tabular}{lc}
\hline Property & Relationship of repair mortar $(R)$ to a concrete substrate $(C)$ \\
\hline Strength in compression, tension, and flexure & $R \geq C$ \\
Modulus in compression, tension, and flexure & $R \sim C$ \\
Poisson's ratio & $R \sim C$ \\
Coefficient of thermal expansion & $R \sim C$ \\
Adhesion in tension and shear & $R \geq C$ \\
Curing and long-term shrinkage & $R \leq C$ \\
Strain capacity & $R \geq C$ \\
Creep coefficient (for repairs in compression) & $R \leq C$ \\
Creep coefficient (for repairs in tension) & $R \geq C$ \\
Fatigue performance & $R \geq C$ \\
Chemical reactivity & $R \leq C$ \\
\hline
\end{tabular}

TABLE 2: Strength requirements for PDR [27].

\begin{tabular}{lrr}
\hline State & Compressive strength, MPa (psi) & Flexural strength, MPa (psi) \\
\hline New York & $10.5(1527)$ & - \\
Kansas & $12.4(1800)$ & $2.1(300)$ \\
Missouri & $11.0(1600)$ & - \\
Michigan & $12.4(1800)$ & $2.1(300)$ \\
Minnesota & $20.7(3000)$ & $3.1(500)$ \\
Colorado & $17.2(2500)$ & - \\
Nebraska & $25.0(3625)$ & - \\
\hline
\end{tabular}

TABLE 3: Minimum opening strength necessary for FDR [28].

\begin{tabular}{|c|c|c|c|c|}
\hline \multirow{3}{*}{ Slab thickness, mm (in.) } & \multicolumn{4}{|c|}{ Strength for opening to traffic, $\mathrm{MPa}$ (psi) } \\
\hline & \multicolumn{2}{|c|}{ Repair length <3 m (10 ft) } & \multicolumn{2}{|c|}{ Slab replacements } \\
\hline & Compressive & 3rd-point flexural & Compressive & 3rd-point flexural \\
\hline $150(6.0)$ & $20.7(3000)$ & $3.4(490)$ & $24.8(3600)$ & $3.7(540)$ \\
\hline $175(7.0)$ & $16.5(2400)$ & $2.6(370)$ & $18.6(2700)$ & $2.8(410)$ \\
\hline $200(8.0)$ & $14.8(2150)$ & $2.3(340)$ & $14.8(2150)$ & $2.3(340)$ \\
\hline $225(9.0)$ & $13.8(2000)$ & $1.9(275)$ & $13.8(2000)$ & $2.1(300)$ \\
\hline$\geq 250(\geq 10.0)$ & $13.8(2000)$ & $1.7(250)$ & $13.8(2000)$ & $2.1(300)$ \\
\hline
\end{tabular}

shrinkage, plastic shrinkage, and drying shrinkage. The magnitude of shrinkage is influenced by several factors such as binder content, water content, aggregates grading and types, as well as usage of admixtures [31-34].

3.2.1. Plastic Shrinkage. Plastic shrinkage occurs when water is lost by surface evaporation or suction by the underlying material. The severity of the contraction depends on the amount of water lost, which is influenced by ambient relative humidity, wind velocity, and temperature [35]. A few measures can be applied to reduce the occurrence of plastic shrinkage in the repair material, i.e., ensure that the evaporation rate does not exceed $1 \mathrm{~kg} / \mathrm{m}^{2}$ per hour and the subgrade must not be dry. The utilisation of a low $\mathrm{w} / \mathrm{c}$ ratio repair mix or fibre reinforcement may help to reduce the occurrence of plastic shrinkage [12]. Concrete with a low w/c has a lower rate of capillary pressure and less tensile stress build-up when the concrete is fresh. The risk of plastic shrinkage is reduced if the water content is less than $150 \mathrm{~kg} / \mathrm{m}^{3}[36,37]$. The addition of synthetic fibre is effective in controlling plastic shrinkage formation [38]. Synthetic fibres such as polyethylene terephthalate, glass, and polypropylene were added to concrete to reduce plastic shrinkage [39]. Polypropylene is the most efficient in restraining plastic shrinkage cracks, where the addition of $0.1 \%$ to $0.3 \%$ fibres is reported to reduce the cracks by $50 \%-99 \%$ compared to plain concrete $[39,40]$. It is noted that all the repair materials should have proper curing.

3.2.2. Drying Shrinkage. Drying shrinkage occurs due to inadequate or improper curing. The volume of concrete changes when moisture is lost to the surrounding. When the material shrinks and is restrained, the tensile stress exerted can reach up to $6.90 \mathrm{MPa}$ [21]. This amount of stress is higher than the tensile strength of a Grade 50 concrete (approximately $4 \mathrm{MPa}$ to $5 \mathrm{MPa}$ ) [41]. High drying shrinkage of the repair materials can cause incompatibility failure [23]; the materials may de-bond if they shrink at a different rate, hence proper curing should be executed after the repair. 
Normally, the maximum allowable shrinkage of repair material used in concrete pavement repair varies from $400 \mu \varepsilon$ to $700 \mu \varepsilon$ at 28 days [42-44]. However, NYSDOT only allows non-shrink repair material [45].

3.2.3. Autogenous Shrinkage. Similar to drying shrinkage, autogenous shrinkage appears within the paste fraction of the repair material. It is more prominent when the $\mathrm{w} / \mathrm{c}$ ratio is less than 0.40 [46]. At low w/c, water is withdrawn from the capillary pores by the hitherto unhydrated cement, thus leading to shrinkage of the paste [35]. Normally, the mix design for repair works requires low water content to achieve high early strength, i.e., w/c ratio of less than 0.40 ; therefore the repair material may be susceptible to autogenous shrinkage cracks.

3.3. Durability. A repair material must be durable and able to maintain its integrity in the environment. It must be able to withstand common physical, chemical, and mechanical attacks experienced in concrete pavement [47]. Deterioration by physical attack includes the effects of high temperature or non-uniform thermal expansion (the differences in thermal expansion of aggregate and the hardened cement paste). Under repeated heating or cooling processes such as alternating freezing and thawing processes, concrete can eventually degrade. Deterioration due to chemical attacks can be in the form of internal and external attacks. The internal chemical attack is associated with the reactive aggregate problem, while the external chemical attack occurs mainly through the action of aggressive ions, such as chlorides, sulphates, or carbon dioxide, as well as many natural or man-made liquids and gases. Mechanical attacks are mostly due to accidental load and overloading.

3.3.1. Freeze-Thaw Requirement. When cementitious material is saturated and exposed to low temperatures, the water within the capillary pores freezes and expands. The produced stress is sufficient to rupture the surrounding material. The cumulative effect of freeze-thaw cycles may degrade the repair material [48].

To ensure that the repair material can withstand the freeze-thaw resistance, authorities have set the minimum durability factor to be $80 \%[45,49]$ or $90 \%$ [42] after a minimum of 300 cycles in accordance with AASHTO T 161 Procedure A (ASTM C666). When tested with ASTM $\mathrm{C} 1262$, the percentage of weight loss in the repair material shall be less than $1.0 \%$ after 100 freeze/thaw cycles using a distilled water solution or less than $1.0 \%$ loss in weight after 50 freeze/thaw cycles when tested in accordance with ASTM C67 [50]. The percentage of weight loss in the repair material shall not be greater than $1.0 \%$ after 25 freeze/thaw cycles [45].

3.3.2. De-Icer Scaling/Deterioration Requirement. De-icer scaling/deterioration is typically characterised by scaling or crazing of the slab surface due to the repeated application of de-icing chemicals in a freeze-thaw environment. The deterioration often appears within the paste fraction. As both osmotic pressures and thermal stress become more prominent, the freeze-thaw effects are magnified [51, 52]. De-icing salts or chemicals exert pressures within the concrete as well as reduce the ability to withstand them [26]. In the process of scaling, calcium hydroxide within the paste is dissolved and the pore system becomes coarser, hence leading to the formation of deleterious compounds [51].

To prevent de-icer scaling in the cementitious repair material, the minimum cement content of the concrete is fixed at $335 \mathrm{~kg} / \mathrm{m}^{3}$ and the maximum w/c ratio shall not exceed 0.45 [51]. When tested under ASTM C672, the scaling resistance of mortar material shall not be greater than $4.88 \mathrm{~kg} / \mathrm{m}^{2}$, while concrete is limited to a maximum visual rating of 2 (slight to moderate scaling) [42]. For high-performance concrete, the limit for visual rating is 3 (moderate scaling) [45].

3.3.3. External Sulphate Attack Requirement. Sulphate attacks can result from external and internal sources. External sulphate attack agents may come from groundwater, soil, deicing chemicals, etc. The sulphate ions penetrate the cementitious system to form ettringite and gypsum, which lead to expansion in the hardened cementitious matrix. Cracks are formed once the tensile strength of the paste is exceeded by the tensile stress created by crystallisation pressure [53]. Another form of damage may be due to the destabilisation of calcium silicate hydrate and calcium hydroxide, resulting in the formation of microcracks without significant expansion.

Prevention of external sulphate attack may be possible by reducing the tricalcium aluminate $\left(\mathrm{C}_{3} \mathrm{~A}\right)$ content in the cement to be less than $8 \%$ [54] or using pozzolanic materials to reduce the quantity of calcium hydroxide in the hydrated cement paste. A w/c ratio should be less than 0.45 to help mitigate external sulphate attacks [53]. When the watersoluble sulphate in dry soil is greater than $2.00 \%$ or in water is greater than $10,000 \mathrm{ppm}$, the maximum $\mathrm{w} / \mathrm{c}$ ratio should be limited to 0.40 [55].

3.3.4. Internal Sulphate Attack Requirement. The internal sulphate attack is similar to the external sulphate attack, except that the source of the sulphate ions is from the internal. The sulphate ions may come from the cement, aggregate, mineral admixture, or the decomposition of primary ettringite when the concrete is cured at high temperatures. Ettringite is usually formed during cement hydration at an early stage. However, due to high concrete temperature, $>65^{\circ} \mathrm{C}$ at an early age, the ettringite formation is suspended [56]. The constituents of ettringite are dispersed as monosulphate and calcium silicate hydrates. When the concrete is moist and the temperature becomes lower, these constituents form secondary ettringite in hardened concrete. Some repair materials may experience high temperatures due to high cement content, high ambient temperature, and heat generated from the thick slab. Therefore, to control internal sulphate attack, the equivalent alkali content of the repair material should be limited to $3 \mathrm{~kg} / \mathrm{m}^{3}$, while $\mathrm{C}_{3} \mathrm{~A}$ in the clinker and $\mathrm{SO}_{3}$ of the cement should be 
less than $8 \%$ and $3 \%$, respectively [57]. The replacement of ordinary Portland cement with supplementary cementitious material (more than $35 \%$ of blast furnace slag, $20 \%$ of fly ash, $20 \%$ of metakaolin, or $10 \%$ of silica fume) may decrease the risk of internal sulphate attack [54]. Proper temperature control shall be adopted to prevent the cementitious repair materials from exceeding the maximum temperature.

3.3.5. Coefficient of Thermal Expansion Requirement. The coefficient of thermal expansion (CoTE) is a property that quantifies the amount of a material that expands and contracts during temperature fluctuation [58]. Generally, the CoTE thermal expansion of repair material ranges from 7.7 to $15.3 \times 10^{-6}$ per ${ }^{\circ} \mathrm{C}$ [59] and for normal concrete, it may range from 7.4 to $13 \times 10^{-6}$ per ${ }^{\circ} \mathrm{C}$ [2]. The compatibility between the thermal properties of repair material and pavement is crucial, as incompatibility between materials can cause detrimental effects such as spalling. When a repair material is subjected to weathering, the temperature cycle causes expansion and contraction of the concrete. Once the tensile stress generated exceeds the tensile capacity of the repair material, cracks and debonding may appear [60]. Concrete having higher CoTE is less resistant to temperature changes than concrete with lower CoTE [51].

3.3.6. Chloride Penetration Requirement. Rapid chloride permeability test (RCPT) (ASTM C1202/AASHTO T 277) is a good indicator to reflect the material durability. The penetration of chloride is measured by the amount of charge passing through the material. A normal concrete $(w / c$ ratio of $0.40-0.50$ ) is expected to exhibit RCPT charge passed ranging between 2000 and 4000 coulombs. Cementitious material with a w/c ratio lower than 0.40 that has RCPT charge passed 1000-2000 coulombs is rated as low chloride permeability [61]. General permeability requirement ranges from 1500 to 2500 coulombs [12, 42, 43, 62]. There are certain cases where the permeability is kept below 1000 coulombs for better durability requirements [63]. However, $\mathrm{RCPT}$ results may be misleading if the repair material contains calcium nitrite [64].

\section{Constituent of the Repair Materials}

Nowadays, the allowable traffic closure time is normally kept minimal to prevent heavy traffic congestion. A lane can be reopened when it meets the strength requirement for traffic opening. Often the suitability of repair material for PDR depends on two major factors: (1) allowable traffic closure time and (2) material properties such as strength, shrinkage characteristic, CoTE, elastic modulus, and creep coefficient $[23,27,65]$.

The minimum time for traffic opening relies on the speed of the repair material to achieve the strength requirement. When using a lower early opening strength patch mixture, the load carry capacity should be determined before being put into service [27]. The early strength repair material can be grouped into 4 types, which are ultra-rapid, rapid, accelerated, and normal strength development [66]. The ultra-rapid repair material can attain sufficient compressive strength and be opened to traffic within 2-4 hours. These materials must be able to achieve $13.8 \mathrm{MPa}$ compressive strength in 2 hours and $20.7 \mathrm{MPa}$ compressive strength in 4 hours. For rapid repair materials, traffic can be opened for service within 6-8 hours. These materials must attain 20.7 MPa compressive strength in 8 hours and $27.6 \mathrm{MPa}$ compressive strength in 3 days. The accelerated concrete repair material is designed to acquire the specified strength within 12 hours. From the perspective of long-term performance, normal concrete outperforms other repair materials. The drawback of normal concrete is that it requires several days to achieve sufficient strength. If no guidance is given, concrete should obtain a minimum of $24.8 \mathrm{MPa}$ compressive strength before being opened to traffic. These non-rapid materials are good quality repair with highly desirable 28 days characteristics [43].

4.1. Ultra-Rapid Material. Generally, there are 4 types of cementitious ultra-rapid material, namely, magnesium phosphate-based, calcium aluminate-based, calcium sulphoaluminate-based, and polymer-modified concrete.

4.1.1. Magnesium Phosphate-Based. Magnesium phosphate cement (MPC) contains no ordinary Portland cement as a binder. It is chemically bonded phosphate ceramic through an acid-base reaction. Generally, the basic material is cationic metal and the acidic part is phosphate [67].

MPC is usually used in areas with very high traffic flow and requires early opening for traffic [68]. MPC repair material can achieve very high early strength $(22.8 \mathrm{MPa})$ within a short period, e.g., 1 hour. The bonding test indicates that MPC exhibits good adhesion to parent concrete, where the bonding test shows that the 1-day and 7-days strengths are $7.17 \mathrm{MPa}$ and $11.51 \mathrm{MPa}$, respectively [69]. The results comply with ASTM C928, the minimum bonding strength required for rapid setting materials is $7 \mathrm{MPa}$ (1 day) and $10 \mathrm{MPa}$ (7 days) [70].

As a pavement repair material, volumetric stability is essential. The MPC repair material has a similar CoTE as concrete $\left(10 \times 10^{-6}\right.$ per $\left.{ }^{\circ} \mathrm{C}\right)$ [41], which is $9.6 \times 10^{-6}$ per ${ }^{\circ} \mathrm{C}$ [71]. It has lower shrinkage (less than $700 \mu \varepsilon$ ) compared to conventional ordinary Portland cement (OPC) mortar (approximate $900 \mu \varepsilon$ ) measured at 28 days [72]. Repair material with lower shrinkage and similar CoTE can have better compatibility. MPC repair material comes with high abrasion resistance, whereby Yang (2014) reported that the abrasion resistance is about double of the normal concrete. With reasonable air content, MPC repair material can perform under freeze-thaw conditions. Scaling of the repair only started after 36 freeze-thaw cycles, while it appears in normal concrete within 10 cycles. [71]. The RCPT result of magnesium phosphate concrete is around 3000 coulombs, while normal concrete is approximately 4000 coulombs. This indicates that magnesium phosphate concrete has a higher resistance to ionic transport [73].

However, the conventional MPC repair material is sensitive to moisture. When exposed to moist conditions, it 
was observed that the mechanical properties of magnesium phosphate cement decrease with time [74]. Water can dilute the unreacted cement, thus increasing the porosity of the system [75]. To mitigate the effect of strength loss, ferroaluminate cement, calcium aluminate cement, or calcium sulphoaluminate cement were added to improve the waterresistant and stability of the magnesium phosphate system [76-78]. MPC is also not suitable to be used with limestone aggregate where the aggregate can accelerate the setting time, decrease the heat of evolution, and degrade the strength, which may be due to poor crystallinity and crystal morphologies of hydration products [79].

\subsubsection{Calcium Aluminate-Based. Calcium aluminate-based} pavement repair material is distinctive from other repair materials due to its early strength. When cured at 6 and $18^{\circ} \mathrm{C}$, the 6 hours compressive strengths are $19 \mathrm{MPa}$ and $24 \mathrm{MPa}$, respectively [80]. Calcium aluminate concrete (CAC) is a low shrinkage concrete, and it develops good bonding properties between the new and old substrate. The CAC may gain strength rapidly due to the formation of $\mathrm{CAH}_{10}$ and $\mathrm{C}_{2} \mathrm{AH}_{8}$ phases [81]. It is resistant to freeze-thaw cycles, as well as de-icing chemicals, besides having high abrasion resistance. It was reported that the CAC has approximately 10 times greater abrasion resistance than silica fume concrete. As a pavement repair material, CAC performs well under low temperatures. The limitation of calcium aluminate-based pavement repair material is strength loss when exposed to high temperatures. At elevated temperatures, the unstable $\mathrm{CAH}_{10}$ phase undergoes conversion to a porous $\mathrm{C}_{3} \mathrm{AH}_{6}$ phase. CAC concrete with $400 \mathrm{~kg} / \mathrm{m}^{3}$ binder and w/c ratio of 0.40 may suffer up to $47 \%$ strength loss after conversion [82]. To address this issue, the performance of the CAC should be evaluated with an accelerated conversion test to ensure the converted strength exceeds the required strength [83]. A recent guideline given by the Texas Department of Transport allows CAC to be used as a pavement repair material, provided the cement content is more than $400 \mathrm{~kg} / \mathrm{m}^{3}$ CAC and the maximum w/c ratio is limited to 0.35 [80]. Similarly, EN 14647 suggests that for structural purposes, the minimum cement content shall not be less than $400 \mathrm{~kg} / \mathrm{m}^{3}$ and the $\mathrm{w} / \mathrm{c}$ ratio shall not be more than 0.40 [82]. The CAC pavement repair material must attain at least $20.7 \mathrm{MPa}$ (cured at ambient temperature) at 3 hours and $27.6 \mathrm{MPa}$ at 24 hours (cured adiabatically) [84].

4.1.3. Calcium Sulphoaluminate-Based. The calcium sulphoaluminate (CSA) repair material has gained popularity due to its rapid strength gain and volumetric stability [85]. CSA contains ye'elimite (C4A3s) as a major constituent (30\% to $70 \%$ ). Unlike CAC, repair material made by CSA does not undergo a conversion process. It is an alternative binder to CAC. This high early strength repair material can achieve compressive strengths of $7 \mathrm{MPa}$ to $28 \mathrm{MPa}$ within 2 hours [86]. Other research has indicated that CSA concrete has a strength greater than $40 \mathrm{MPa}$ at 6 hours [85]. In terms of volumetric stability, it was reported that the magnitude of shrinkage is half of that for high early strength Portland cement [87]. Besides that, CSA-based concrete can perform at a temperature of under $5^{\circ} \mathrm{C}[88]$. CSA-based concrete is a good anti-freeze material, where under freeze-thaw performance testing, CSA repair material was found to have $12 \%$ less weight loss compared to OPC concrete [89]. Also, CSA-based concrete exhibits good resistance to corrosion and chemical attacks such as sulphate, magnesium, and ammonium salts [81, 90]. Hargis et al. (2017) revealed that at the same $w / c$, the oxygen diffusion coefficient and water absorption of CSA concrete is $35 \%$ and $58 \%$, respectively, of OPC concrete [91]. The electrical resistivity of CSA concrete is 21 times better than normal concrete [92]. Although there is concern about the risk of reinforcement corrosion due to the increment of chloride ions in pore solution when CSA concrete is exposed to chloride condition [93], Jen et al. (2017) has shown that by altering the calcium sulphate-toye'emilite ratio, the chloride-binding capability can be enhanced, which may help to resolve the issue [94]. According to Dam et al. (2005), the local authority of California has specified CSA pavement repair as its rapid repair material and requires CSA-based concrete to achieve at least $2.8 \mathrm{MPa}$ flexural strength at 8 hours [51].

4.1.4. Polymer-Modified Concrete. Polymer-modified concrete (PMC) refers to the addition of latex (powder or liquid) to a cementitious-based material. When cured, the resulting concrete contains a continuous, interconnected matrix of latex polymer particles [13]. Common polymers such as acrylics, styrene acrylics (SA), vinyl acetate-ethylene (VAE) copolymers, styrene-butadiene rubber (SBR) co-polymer, vinyl ester of versatic acid (VeoVa), and epoxies are added into the cementitious material to improve the physical and durability properties [95].

PMC is considered as one of the cheapest high-performance pavement repair materials. It is often used in the area where traffic volume is very high and only allows short closure time, e.g., within 2 hours. The working temperature of this material is between 7 and $29^{\circ} \mathrm{C}$. Normally, PMC is designed with a life span of 5 years [96].

PMC has high adhesion strength between concrete substrates [97]. The flexural and shear bond test results have revealed a bond strength increase of $32 \%$ and $120 \%$, respectively, compared to normal concrete [98]. In terms of volumetric stability, Weng et al. reported that the drying shrinkage of polymer-modified cementitious repair material is below $200 \mu \varepsilon$ [99], which is lower than most transport authority's requirements of $400-700 \mu \varepsilon$ [42-44]. The PMC repair material also exhibits good thermal compatibility, where the CoTE is around $10-20 \times 10^{-6}$ per ${ }^{\circ} \mathrm{C}$, which is similar to normal concrete [100]. Apart from that, the high abrasion resistance and lower susceptibility to the freezethaw attack of PMC allow it to perform well under traffic exposure. As described by Mirza et al. (2002), the weight loss of PMC due to abrasion is only $28 \%$ of the silica fume concrete control sample. After 300 freeze-thaw cycles, the recorded weight loss of PMC is below $1 \%$, while control samples recorded weight loss greater than $2 \%$ [101]. Lee et al. (2018) reported that the chloride ion penetration of PMC 
repair material is less than 1500 coulombs at 28 days and less than 1000 coulombs when tested at 56 days [102]. Low ionic transportation of PMC indicates that it is a durable repair material.

4.2. Rapid Repair and Accelerated Repair Materials. Rapid and accelerated repair materials are made from high early strength Portland cement and normal cement. High early strength cement contains a high percentage of alite $\mathrm{C}_{3} \mathrm{~S}$ to give rapid hardening and setting properties [103]. In European standard, high early strength cement is categorised as "R," while normal strength gain cement is denoted as " $N$ " [104]; ASTM C150 classifies high early strength cement under Type III cement, while normal Portland cement as Type I cement [105]. The typical Blaine fineness of high early strength cement is $556 \mathrm{~m}^{2} / \mathrm{kg}$, while the Blaine fineness of OPC is $384 \mathrm{~m}^{2} / \mathrm{kg}$ [103]. Fast-track concrete normally consists of high cement content and low w/c ratio, which leads to early strength development. The summary of fasttrack concrete is shown in Table 4 . With the addition of accelerators in the concrete mix, the setting time can be shortened, and early strength can be achieved through the modification of cement hydration. The accelerator is commonly dosed at $1.25 \%-3.75 \%$ of cement content [106].

Generally, the accelerator can be in the form of soluble inorganic salts and soluble organic compounds. The most common accelerator is calcium chloride, which is inexpensive and readily available. However, it has a detrimental effect on steel reinforcement [111]. Non-chloride accelerators such as nitrates, thiocyanates, alkanolamines, formates, acetates, and alkaline hydroxides do not promote steel corrosion. Although there are various alternative accelerators, none of these outperforms the chloride-based accelerator. The chloride-based accelerator has the lowest costperformance ratio compared to the non-chloride accelerator $[111,112]$.

The fast-track repair material comes with costs; it was reported that some high early strength repair materials may encounter poorer freeze-thaw performance. The amount of entrained air within the concrete is reduced due to the high fineness of cement and high-range water reducers. The performance can be further reduced if a calcium chloride accelerator was used [113]. The shrinkage of fast-track concrete is also higher due to its higher binder content. In contrast to freeze-thaw resistance, the wear resistance and resistance to external sulphate attack performed well due to the low w/c ratio and high binder content $[108,114]$.

4.3. Normal Strength Concrete. Normal strength concrete is made from cement, water, coarse and fine aggregates, admixtures, and sometimes with the addition of supplementary cementitious material. It can be easily designed based on guidelines provided by British Research Establishment or American Concrete Institute $[115,116]$. It is known as concrete with strength less than $55 \mathrm{MPa}$ [117]. Depending on the traffic and exposure, the required compressive strength of normal paving concrete ranges from $20 \mathrm{MPa}$ to $55 \mathrm{MPa}$ $[49,107,118]$. When the concrete is designed with normal strength gain cement, the strength development is considered slow, unlike rapid gain strength repair material, which can achieve the required strength within several hours. The 1-day and 7-day strength is predicted to be approximately $34 \%$ and $78 \%$ of the 28 -day strength, respectively [41]. Unlike accelerated repair material, normal strength concrete has lower binder content and higher aggregate content, hence it performs better in terms of shrinkage [21]. Table 5 shows the design mixes of normal strength concrete.

\subsection{The Newly Developed Repair Material}

4.4.1. Ultra-High Performance Concrete. In the year of 1994, Richard and Cheyrezy had successfully developed reactive powder concrete with compressive strength up to $800 \mathrm{MPa}$ [122]. Since then, the race to develop ultra-high performance concrete (UHPC) has started. Although no clear definition of UHPC has been adopted, some researchers recognise UHPC as concrete to have a minimum compressive strength of $120 \mathrm{MPa}$ with strain-hardening capability [123]. For structural UHPC, it is recommended that the concrete shall have at least $150 \mathrm{MPa}$ compressive strength and with tensile strength greater than $6 \mathrm{MPa}[14,124]$. The earlier version of UHPC is made of cement, silica fume, quartz sand, fibre, quartz powder, and superplasticizer [122, 125]. Later, "greener" UHPC has been developed, which incorporated fly ash, slag, and limestone powder as well as other eco-friendly binders [126-129]. A summary of the UHPC mix design is shown in Table 6.

The performance of UHPC has exceeded the basic requirements of conventional concrete pavement repair materials. It has very low porosity and improves fatigue behaviour, which is excellent for pavement repair. In short, UHPC has no significant failure after $10^{6}$ load cycles [135]. The fatigue performance of UHPC is affected by the strength of the material, stress applied, fibre distribution, and testing specimen [136-138].

UHPC has very high early strength, which exceeds $50 \mathrm{MPa}$ within 24 hours [139]. It is beneficial for the early opening-to-traffic. Surface damage due to abrasion is the least concern; it was reported that the weight loss of UHPC when subjected to abrasion resistance test is only $40 \%$ of that for ordinary concrete [140]. As a repair material, the bond between the original substrate and repair material can determine the effectiveness of the repair material. A field test has been carried out to determine the bonding between UHPC with the original substrate. Results indicate that adequate bonds are developed between the UHPC and the original substrate even without surface treatment (diamond grounding) to the substrate. However, the interface voids must be below $10 \%$ for better bonding to be developed and the substrate must be sound concrete. [141]. Figure 1 shows the interface between UHPC and the old substrate.

With high fibre content and low water-to-binder ratio, UHPC has lower drying shrinkage. However, the autogenous shrinkage of UHPC is higher than ordinary concrete. The autogenous shrinkage of UHPC can easily reach up to $1500 \mu \varepsilon$. Hence, autogenous shrinkage dominates the total 
TABle 4: Typical ranges of constituent materials for high early strength concrete [51, 106-110].

\begin{tabular}{lcccc}
\hline $\begin{array}{l}\text { Mix } \\
\text { characteristic }\end{array}$ & $4-6$ hours concrete & $6-8$ hours concrete & $12-16$ hours concrete & $20-24$ hour concrete \\
\hline Cement type & Normal or high early & Normal or high early strength & Normal or high early strength & Normal or high early strength \\
& strength & or blended & or blended & or blended \\
Cement content & $385-565 \mathrm{~kg} / \mathrm{m}^{3}$ & $385-565 \mathrm{~kg} / \mathrm{m}^{3}$ & $420-500$ & $400-475 \mathrm{~kg} / \mathrm{m}^{3}$ \\
W/c ratio & $0.32-0.40$ & $0.36-0.40$ & $0.32-0.46$ & $0.40-0.47$ \\
Accelerator & Yes & Yes & None to yes & None to yes \\
\hline
\end{tabular}

TABLE 5: Mix design for normal strength concrete.

\begin{tabular}{|c|c|c|c|c|c|c|c|c|}
\hline $\mathrm{CM}$ & $\mathrm{W}$ & G & $S$ & SP & AEA & $\mathrm{W} / \mathrm{cm}$ & Compressive strength (MPa) & References \\
\hline 415 & 208 & 1049 & 729 & - & 0.0415 & 0.50 & 50 & [119] \\
\hline 390 & 156 & 1297.8 & 566.2 & 1.95 & & 0.40 & 50 & \\
\hline 320 & 160 & 1286.4 & 633.6 & 1.92 & & 0.50 & 40 & {$[120]$} \\
\hline 280 & 168 & 1249.3 & 702.7 & 1.68 & & 0.60 & 30 & \\
\hline 400 & 200 & 930 & 873 & 4 & & 0.50 & 40 & {$[121]$} \\
\hline
\end{tabular}

CM: cement/silica fume/fly ash/ground granulated furnace slag; W: water; G: coarse aggregate; S: fine aggregate; SP: superplasticizer; AEA: air-entraining agent; w/cm: water/cementitious material.

shrinkage of the concrete. Instability in dimension caused by autogenous shrinkage leads to debonding of the repair material. Mitigation can be done by controlling the hydration rate, using shrinkage reducing admixture or expansive agent [142]. Providing more internal restrain within the concrete matrix may help to reduce autogenous shrinkage; stiff or high elastic modulus aggregates can restrain the shrinkage deformation [142]. It was reported that an increase in the total aggregate volume may decrease the autogenous shrinkage up to $38 \%$ [143]. Besides that, providing internal curing agents such as a superabsorbent polymer or moist porous aggregate may lead to lower autogenous shrinkage. Liu et al. (2019) has demonstrated that optimising UHPC with porous pumice can reduce the shrinkage from $700 \mu \varepsilon$ (E0) to less than $300 \mu \varepsilon$ (E1-E6), as shown in Figure 2 [144].

Due to the dense matrix, UHPC has lower porosity, which can be reflected by the chloride ion diffusion coefficient, $D_{\text {eff. }}$ The $D_{\text {eff }}$ of UHPC is in the range from $0.2 \times 10^{-13}$ to $4.1 \times 10^{-14} \mathrm{~m}^{2} / \mathrm{s}$, while for normal grade 30 and grade 80 concretes, the $D_{\text {eff }}$ is $1.1 \times 10^{-12} \mathrm{~m}^{2} / \mathrm{s}$ and $6 \times 10^{-13} \mathrm{~m}^{2} / \mathrm{s}$, respectively [145]. Furthermore, it was noted that under 5-15 years of freeze-thaw cycles in marine condition, no deterioration was detected on UHPC. The depth of chloride penetration of UHPC is only one-third of high-performance concrete with water-to-binder of 0.33 and $8.5 \%$ silica fume [146]. After 1000 cycles of freeze-thaw in the salt solution, it was reported that the compressive strength decreases about $17 \%$, while major strength loss of up to $41.6 \%$ only occurs after 1500 freeze-thaw cycles, indicating that the high resistance of UHPC in freeze-thaw condition [147]. In general, the freeze-thaw performance is influenced by the water-tobinder ratio, amount of supplementary cementitious material, and steel fibre. The optimum content of silica fume, fly ash, and steel fibre is $80-130 \mathrm{~kg} / \mathrm{m}^{3}, 60-100 \mathrm{~kg} / \mathrm{m}^{3}$, and $25-50 \mathrm{~kg} / \mathrm{m}^{3}$, respectively [148]. Apart from freeze-thaw resistance, UHPC shows low or no sign of scaling after the test [149]. With its excellent performance, UHPC is a potential material for pavement repair material.

4.4.2. Alkali-Activated Materials. Sustainable development has emerged into a trend that leads to the development of "greener" construction material. Alkali-activated material (AAM) is an eco-efficient binder that is developed by activating an aluminosilicate precursor with an alkali medium. Common precursors are fly ash, slag, metakaolin, phosphorus slag, red mud, etc. The activators referred are sodium hydroxide, sodium silicate, sodium carbonate, etc. The usage of AAM can greatly reduce the carbon footprint up to $80 \%$ compared to OPC [150]. Table 7 shows the type of precursor and the resulting mechanical properties.

The early strength requirement is one of the crucial parameters for pavement repair. Conventional AAM requires high temperature for curing to acquire better early strength properties. A recent study shows that ternary blended AAM (slag, metakaolin, and fly ash) without hightemperature curing can achieve very high early strength, which exceeds $70 \mathrm{MPa}$ within a day [152]. Thus, it is very useful for emergency repair. Electric arc furnace slag with fly ash as an additive in AAM could record more than $50 \mathrm{MPa}$ within 7 days [159], and it may be used as a substitute for normal strength gain concrete repair material, which requires 28 days to achieve $50 \mathrm{MPa}$.

The performance of AAM is comparable with ordinary concrete or better when exposed to a severe environment [152, 160-162]. It was reported that the AAM outperforms ordinary concrete in abrasion resistance, and the depth of wear of AAM is approximately $40 \%$ of ordinary concrete [163]. Furthermore, volumetric stability is crucial for a repair material, as high shrinkage within the repair material may lead to debonding of the material with the original substrate. Although previous research indicates that the drying shrinkage of certain AAMs is 3-6 times higher than ordinary 


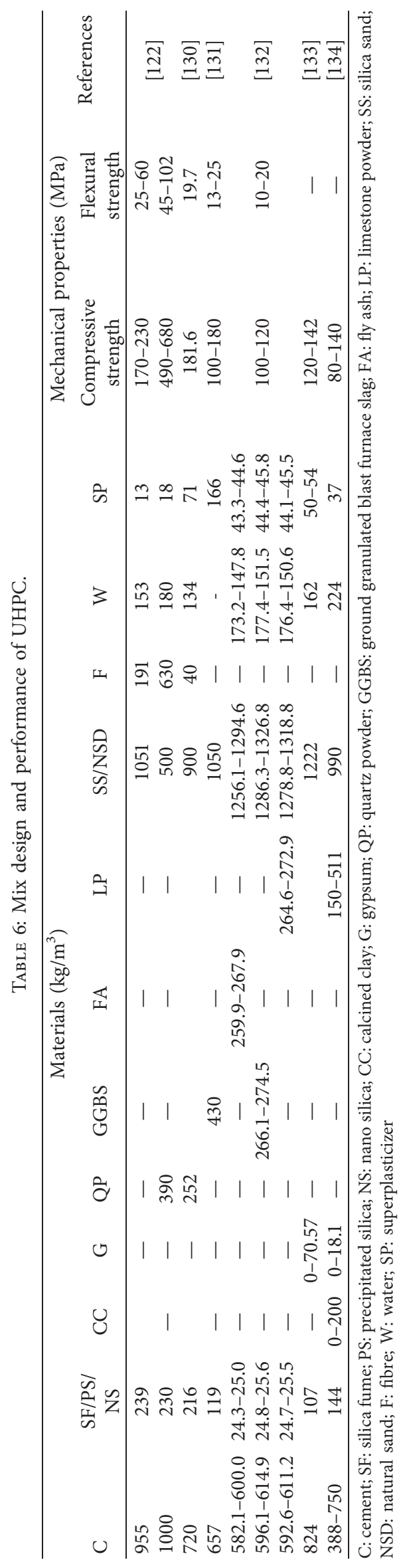




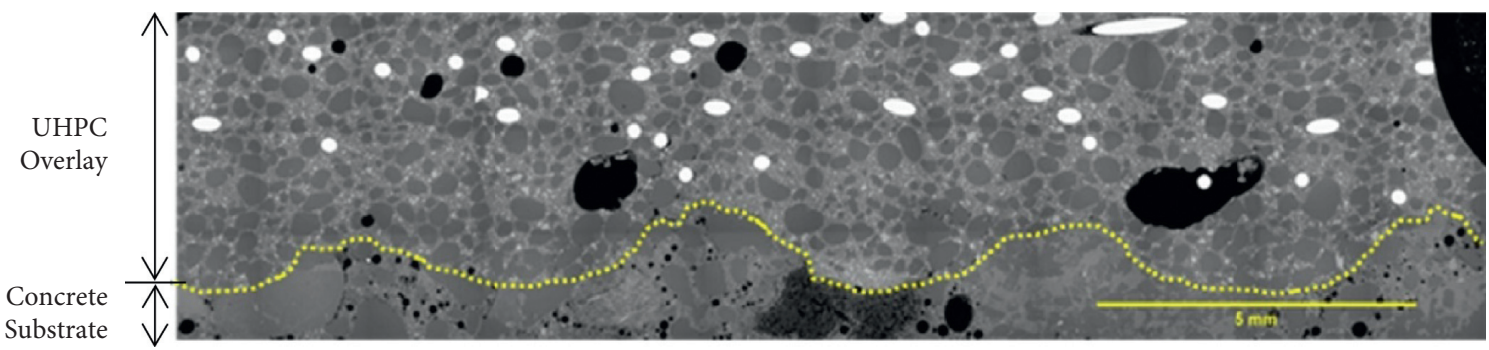

(a)

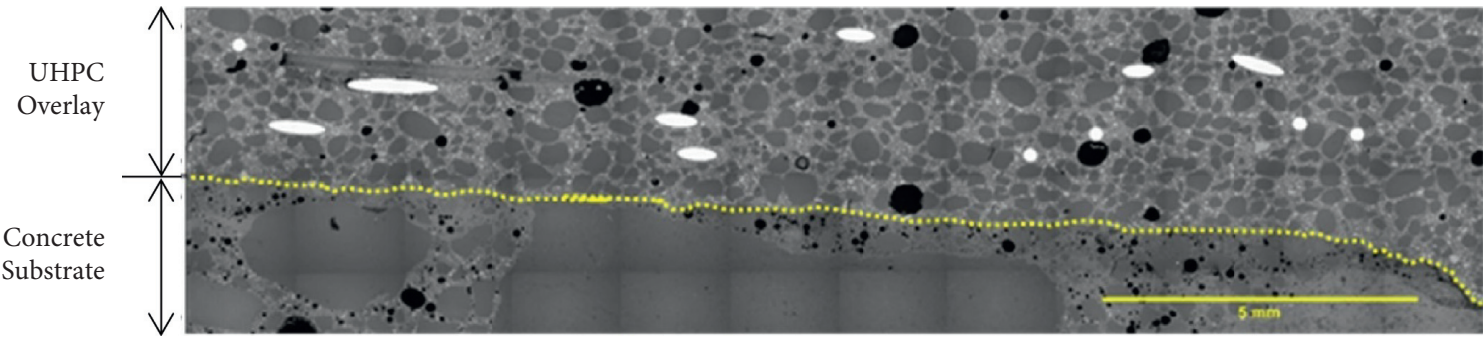

(b)

Figure 1: Interface between UHPC and substrate [141]. (a) Diamond ground surface. (b) No surface treatment.

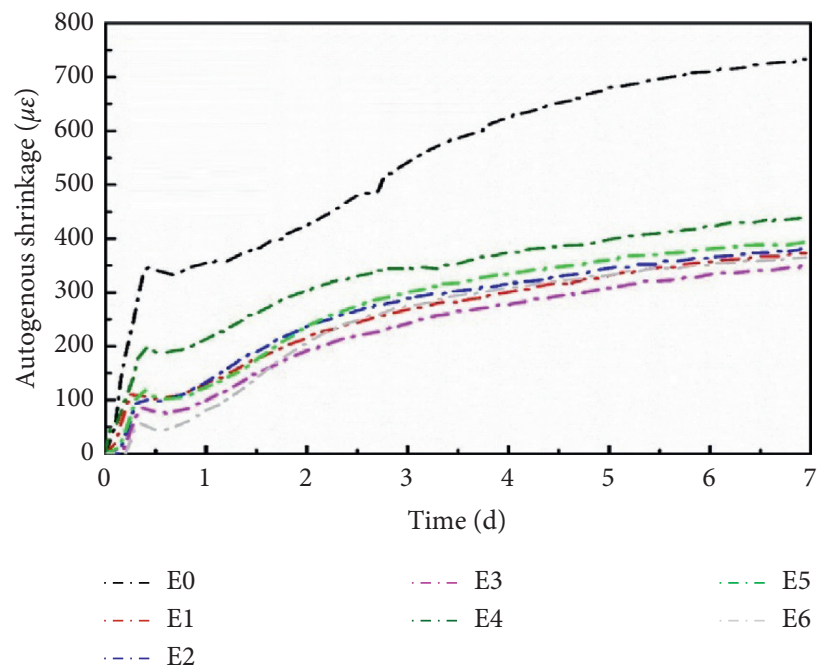

FIgURE 2: Autogenous shrinkage of UHPC with (E1-E6) and without porous aggregate (E0) [144].

TABle 7: Type of AAM and mechanical performance.

\begin{tabular}{|c|c|c|c|c|c|c|}
\hline Precursor & Activator & $\begin{array}{l}\text { Liquid/ } \\
\text { binder }\end{array}$ & Curing condition & $\begin{array}{c}\text { Compressive strength } \\
(\mathrm{MPa})\end{array}$ & $\begin{array}{c}\text { Flexural } \\
\text { strength }(\mathrm{MPa})\end{array}$ & References \\
\hline $\begin{array}{l}\text { Fly ash/calcined } \\
\text { carbonation lime residue }\end{array}$ & $\mathrm{SS}+\mathrm{SH}$ & 0.5 & Room temperature & $\begin{array}{c}\text { Approximately } \\
35 \mathrm{MPa}\end{array}$ & & [151] \\
\hline Slag/metakaolin/fly ash & $\mathrm{SS}+\mathrm{SH}$ & 0.34 & Room temperature & $>80 \mathrm{MPa}$ & & {$[152]$} \\
\hline Metakaolin/slag & $\mathrm{SS}+\mathrm{SH}$ & 0.7 & $50^{\circ} \mathrm{C}$ & 63.6 & 10.6 & [153] \\
\hline High calcium fly ash & $\begin{array}{c}\text { SS } \\
\text { (anhydrous) }\end{array}$ & 0.25 & $25^{\circ} \mathrm{C}$ & 50 & & {$[154]$} \\
\hline $\begin{array}{l}\text { Ti-extracted residue/fly } \\
\text { ash }\end{array}$ & $\mathrm{SH}$ & 0.5 & $20^{\circ} \mathrm{C}$ & 63.6 & Approx. 6.5 & [155] \\
\hline Metakaolin/slag & $\mathrm{SS}+\mathrm{SH}$ & $0.5-1.1$ & $\begin{array}{c}\text { Dry ambient curing/ } \\
\text { humidification } / 40 \pm 5^{\circ} \mathrm{C}\end{array}$ & $41-60$ & & {$[156]$} \\
\hline GGBS/pumice/slag & $\mathrm{SS}+\mathrm{SH}$ & 0.5 & $\begin{array}{c}20-25^{\circ} \mathrm{C} \text { relative humidity: } \\
40 \%\end{array}$ & $36.55-63.95$ & $3.98-5.66$ & [157] \\
\hline $\begin{array}{l}\text { Metakaolin/fly ash/silica } \\
\text { fume }\end{array}$ & $\mathrm{PS}+\mathrm{PH}$ & & $25^{\circ} \mathrm{C}$ & 80.7 & & [158] \\
\hline
\end{tabular}

SS: sodium silicate; SH: sodium hydroxide; PS: potassium silicate; PH: potassium hydroxide. 


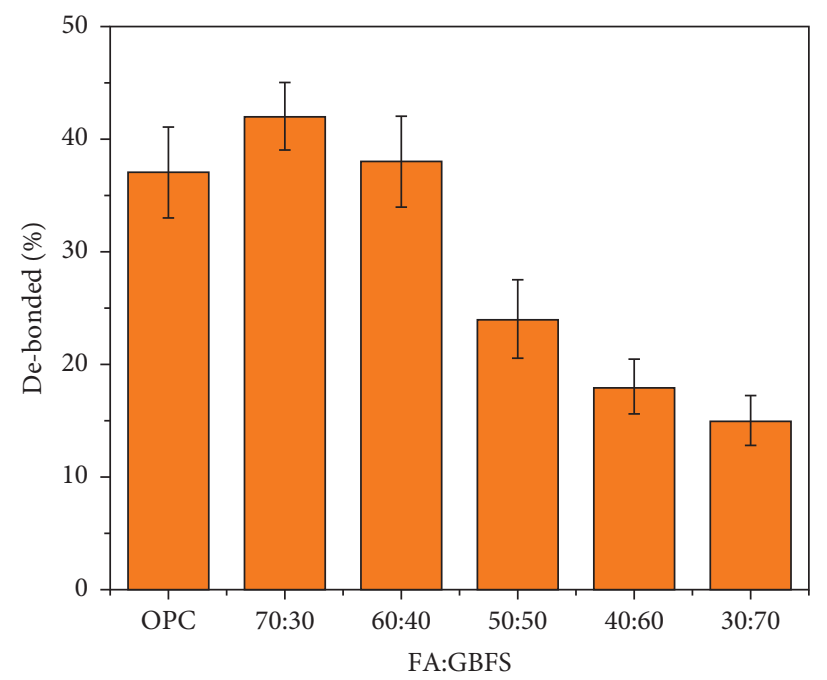

Figure 3: Percentage of de-bonded areas with different AAM composition [169].

concrete due to the activator $[164,165]$, mitigation can be done by incorporating shrinkage reducing admixture and gypsum [166, 167]. The incorporation of lightweight shale aggregate in AAM has proven to reduce the autogenous shrinkage by $50 \%-75 \%$ [168].

Recent research reported that the bonding between concrete and binary blended AAM (fly ash and slag) is encouraging. AAM with high slag content (Fly ash: Slag $\geq 50$ : 50) outperforms OPC repair material. Figure 3 indicates the percentage of de-bonded areas with different compositions of binary AAM [169].

Failure of repair material is often related to the ability to withstand the environmental load. Binary AAM with high content of slag performs better and retains more residual strength after the freeze-thaw cycle $[169,170]$. Thus, the potential of AAM as a repair material for concrete pavement is promising.

\section{Conclusions}

This paper reviewed the different types of cementitious repair materials. This was done by gathering 171 different research articles, guidelines, and standards related to concrete pavement. The following are the major conclusions derived from this study:

Repair materials are expected to have a service life between 5 and 15 years, hence a repair material needs to be designed to be compatible with the original substrate. Compatibility of the repair material includes mechanical properties (strength, modulus, adhesion, and strain capacity), dimension stability (Poisson's ratio, thermal stability, and shrinkage), and long-term performance (creep, fatigue, and chemical reactivity).

A repair material must fulfill certain strength requirements before being opened to traffic. For PDR, the required compressive strength ranges from $11 \mathrm{MPa}$ to $13 \mathrm{MPa}$. The required compressive strength for FDR is influenced by the repair size, and this ranges from $13.8 \mathrm{MPa}$ to $20.7 \mathrm{MPa}$ or flexural strength of approximately $4.5 \mathrm{MPa}$.
The volumetric stability of the repair material is crucial. For a repair material, it is normally designed with high binder content and low w/c. Hence, it is susceptible to plastic, drying, and autogenous shrinkage. Normally, the drying shrinkage is limited to $0.04 \%-0.07 \%$ at 28 days.

The minimum durability factor for freeze-thaw resistance is at least $80 \%$ in accordance with AASHTO T 161 Procedure A. If tested according to ASTM C1262 or ASTM C67, the percentage of weight loss in the repair material shall be less than $1.0 \%$ after the freeze-thaw cycles.

The scaling resistance of mortar material shall not be greater than $4.88 \mathrm{~kg} / \mathrm{m}^{2}$ when tested with ASTM C672. For normal concrete, the visual rating is limited to 2 (slight to moderate scaling), while it is limited to 3 (moderate scaling) for high-performance concrete.

To prevent external sulphate attack, the repair concrete must have a maximum w/c of 0.45 . For internal sulphate attack, the equivalent alkali content within the repair material should be limited to $3 \mathrm{~kg} / \mathrm{m}^{3}$, while $\mathrm{C}_{3} \mathrm{~A}$ in the clinker and $\mathrm{SO}_{3}$ of the cement should be less than $8 \%$ and $3 \%$, respectively. Suitable cement replacement can be adopted to reduce the risk of internal sulphate attack.

The CoTE of the repair material and original substrate (normal concrete) must be similar to prevent debonding of the material. A durable repair material can be reflected by the permeability which is normally limited between 1500 and 2500 coulombs when tested with a RCPT.

A repair material can be categorised by the speed of gain strength and can be grouped into ultra-rapid, rapid, accelerated, and normal strength repair material.

Depending on the area of usage, for emergency repairs such as an airfield, road junction, or high-volume freeway, the preferred material would be ultra-rapid material (2-4 hours traffic opening time), which can be made from magnesium phosphate, calcium aluminate, calcium sulphoaluminate, and polymer-modified cementitious binder.

In the event where traffic is required to open within 4-24 hours, rapid and accelerated repair material may be used. These materials are made of high early strength cement with 
accelerator and designed with higher cement content. When traffic opening time is greater than 6 hours, blended cement with fly ash and slag may be incorporated into the concrete mix. The required binder content can be decreased with increased opening time. The high dosage of binder content and low water-binder ratio lead to an increase in the total shrinkage due to autogenous shrinkage and drying shrinkage.

For better long-term performance, concrete pavement repair with normal concrete is the best solution. Normal concrete is accompanied by lower binder content. Hence, it is more stable in terms of volumetric changes and can be more compatible with the existing pavement material. Also, normal concrete can be readily available and at a lower price.

Newly produced construction materials such as UHPC and AAM have high potential to be used as concrete pavement repair material. Besides the higher mechanical properties such as compressive and flexural strengths, they are more durable than normal concrete when exposed to a harsh environment as reflected by the better abrasion and freeze-thaw resistance. Both materials also have good bonding between the original substrate, which can ensure no debonding issue.

\section{Data Availability}

No data were used to support this study.

\section{Conflicts of Interest}

The authors declare that there are no conflicts of interest regarding the publication of this paper.

\section{Acknowledgments}

This work was supported by Universiti Malaya under the grant PG163-2015A (Innovative Development of Very High Early Strength Concrete for Highway Repair Industry).

\section{References}

[1] A. H. Blanchard, American Highway Engineers' Handbook, John Wiley \& Sons Incorporated, Hoboken, NJ, USA, 1919.

[2] N. J. Delatte, Concrete Pavement Design, Construction, and Performance, Taylor \& Francis, Oxford, UK, Second edition, 2014.

[3] A. Loijos, N. Santero, and J. Ochsendorf, "Life cycle climate impacts of the US concrete pavement network," Resources, Conservation and Recycling, vol. 72, pp. 76-83, 2013.

[4] M. S. Luke and G. S. Billie, "Oldest concrete street in the United States," Concrete International, vol. 24, no. 3, pp. 72-74, 2002.

[5] R. K. Dhir, J. D. Brito, R. V. Silva, and C. Q. Lye, "Use of recycled aggregates in road pavement applications," in Sustainable Construction Materials; Woodhead Publishing Series in Civil and Structural Engineering, pp. 451-494, Woodhead Publishing, Sawston, UK, 2019.

[6] J. Gross, "Guidance for Improving Foundation Layers to Increase Pavement Performance on Local Roads," National Concrete Pavement Technology Center, Ames, IA, USA, IHRB Project TR-640, 2014.
[7] Federal Highway Administration, Public Road Length- 2018 (1) Miles by Type of Surface and Ownership/Functional System National Summary, Federal Highway Administration, Washington, DC, USA, 2018.

[8] MLIT Japan, Road Statistics Annual Report, MLIT, Tokyo, Japan, 2018.

[9] K. Hall, D. Dawood, S. Vanikar et al., Long-Life Concrete Pavements in Europe and Canada, Federal Highway Administration U.S. Department of Transportation, American Association of State Highway and Transportation Officials, Washington, DC, USA, 2007.

[10] S. Pranav, S. Aggarwal, E. H. Yang, A. K. Sarkar, A. S. Pratap, and M. Lahoti, "Alternative materials for wearing course of concrete pavements: a critical review," Construction and Building Materials, vol. 236, Article ID 117609, 2020.

[11] N. Khomnamool, P. Taneerananon, S. Srilenawat, and P. Thongchim, "New approach to pavement management system in Thailand," Proceedings of the Eastern Asia Society for Transportation Studies, vol. 6, 2007.

[12] D. Harrington, M. Ayers, C. Tom et al., Guide For Concrete Pavement Distress Assessments And Solutions: Identification, Causes, Prevention, and Repair, National Concrete Pavement Technology Center, Ames, IA, USA, 2018.

[13] Cement Concrete \& Aggregates Australia, Concrete Pavement Maintenance/Repair, Cement Concrete \& Aggregates Australia, New South Wales, Australia, 2009.

[14] B. Graybeal, Design and Construction of Field-Cast UHPC Connections, p. 36, FHWA, Washington,DC, USA, 2019.

[15] A. K. Akhnoukh and C. Buckhalter, "Ultra-high-performance concrete: constituents, mechanical properties, applications and current challenges," Case Studies in Construction Materials, vol. 15, Article ID e00559, 2021.

[16] A. M. Rashad and M. Gharieb, "Valorization of sugar beet waste as an additive for fly ash geopolymer cement cured at room temperature," Journal of Building Engineering, vol. 44, Article ID 102989, 2021.

[17] P. Perumal, H. Sreenivasan, T. Luukkonen et al., "High strength one-part alkali-activated slag blends designed by particle packing optimization," Construction and Building Materials, vol. 299, Article ID 124004, 2021.

[18] J. L. Provis, A. Palomo, and C. Shi, "Advances in understanding alkali-activated materials," Cement and Concrete Research, vol. 78, pp. 110-125, 2015.

[19] A. Setyawan, S. E. Zoorob, and K. E. Hasan, "Investigating and comparing traffic induced and restrained temperature stresses in a conventional rigid pavement and semi-rigid layers," Procedia Engineering, vol. 54, pp. 875-884, 2013.

[20] G. R. Rada, D. J. Jones, J. T. Harvey, K. A. Senn, and M. Thomas, NCHRP Report 747 Guide for Conducting Forensic Investigations of Highway Pavements, National Academy of Sciences, Washington, D.C, USA, 2013.

[21] K. Smith, D. Harrington, L. Pierce, P. Ram, and K. Smith, Concrete Pavement Preservation Guide, Federal Highway Administration, Washington, D.C., USA, 2014.

[22] D. G. Peshkin, K. L. Smith, A. Wolters, J. Krstulovich, J. Moulthrop, and C. Alvarado, Guidelines For the Preservation Of High-Traffic-Volume Roadways, Transportation Research Board, Washington, DC, USA, 2011.

[23] D. R. Morgan, "Compatibility of concrete repair materials and systems," Construction and Building Materials, vol. 10, no. 1, pp. 57-67, 1996.

[24] N. K. Emberson and G. C. Mays, "Significance of property mismatch in the patch repair of structural concrete Part 1: 
properties of repair systems," Magazine of Concrete Research, vol. 42 , no. 152 , pp. 147-160, 1990.

[25] B. Kiani, R. Y. Liang, and J. Gross, "Material selection for repair of structural concrete using VIKOR method," Case Studies in Construction Materials, vol. 8, pp. 489-497, 2018.

[26] D. Cusson and M. Noel, "Durability of repair materials," Concrete International, vol. 18, no. 3, 1996.

[27] D. P. Frentress and D. S. Harrington, Guide for Partial Depth Repair of Concrete Pavements, Institute for Transportation Iowa State University, Ames, IA, USA, 2012.

[28] Acpa, Concrete Pavement Field Reference-Preservation and Repair, American Concrete Pavement Association, Skokie, IL, USA, 2006.

[29] Highway England, "Manual of contract documents for highway works volume 1 specification for highway works," in Series 1000 Road Pavements- Concrete MaterialsHighways England, Birmingham, UK, 2020.

[30] Z. Collier, A. Raghavendra, and T. Rupnow, Final Report 589 Reliable Early Opening Strength for Concrete Pavements and Patch Work, Louisiana Transportation Research Center, Baton Rouge, LA, USA, 2018.

[31] B. W. Jo, M. A. Sikandar, Z. Baloch, A. Naseer, N. Jan, and Q. Jamal, "Effect of w/b ratio and binder content on the properties of self-compacting high performance concrete (SCHPC)," Journal of Ceramic Processing Research, vol. 19, pp. 171-178, 2018.

[32] W. Zhang, M. Zakaria, and Y. Hama, "Influence of aggregate materials characteristics on the drying shrinkage properties of mortar and concrete," Construction and Building Materials, vol. 49, pp. 500-510, 2013.

[33] M. E. Karaguler and M. S. Yatagan, "Effect of Aggregate Size on the Restrained Shrinkage of the concrete and Mortar," MOJ Civil Engneering, vol. 4, no. 1, 2018.

[34] M. Kioumarsi, F. Azarhomayun, M. Haji, and M. Shekarchi, "Effect of shrinkage reducing admixture on drying shrinkage of concrete with different w/c ratios," Materials, vol. 13, no. $24,2020$.

[35] A. M. Neville, Properties of Concrete, Pearson Education, London, UK, 2012.

[36] F. Sayahi, M. Emborg, and H. Hedlund, "Effect of watercement ratio on plastic shrinkage cracking in self-compacting concrete," in Proceedings of the 23rd Nordic Concrete Research Symposium, Aalborg, Denmark, August 2017.

[37] C. Ishee and S. Surana, "Hot weather concreting," in Developments in the Formulation and Reinforcement of Concrete, S. Mindess, Ed., pp. 131-150, Woodhead Publishing, Sawston, Cambridge, UK, Second edition, 2019.

[38] M. Serdar, A. Baričević, M. J. Rukavina, M. Pezer, D. Bjegović, and N. Štirmer, "Shrinkage behaviour of fibre reinforced concrete with recycled tyre polymer fibres," International Journal of Polymer Science, vol. 2015, Article ID 145918, 9 pages, 2015.

[39] F. Pelisser, A. B. D. S. S. Neto, H. L. L. Rovere, and R. C. D. A. Pinto, "Effect of the addition of synthetic fibers to concrete thin slabs on plastic shrinkage cracking," Construction and Building Materials, vol. 24, no. 11, pp. 21712176, 2010.

[40] G. M. I. Sadiqul and S. D. Gupta, "Evaluating plastic shrinkage and permeability of polypropylene fiber reinforced concrete," International Journal of Sustainable Built Environment, vol. 5, no. 2, pp. 345-354, 2016.

[41] British Standards Institution, BS EN 1992-1-1:2004+A1:2014 Eurocode 2: Design of concrete Structures Part 1-1: General Rules and Rules for Buildings, BSI, London, UK, 2014.
[42] WSDOT, Standard Specifications for Road, Bridge, and Municipal Construction, Washington State Department of Transportation, Olympia, DC, USA, 2020.

[43] TxDOT, Departmental Materials Specification DMS-4655, Texas Department of Transportation, Austin, TX, USA, 2017.

[44] MDOT, Standard Specifications for Construction and Materials, Maryland Department of Transportation, Hanover, Germany, 2018.

[45] NYSDOT, Standard Specifications (Metric Units) Construction and Materials, p. 1328, NYSDOT, Albany, NY, USA, 2017.

[46] S. Jianxia, "Durability design of concrete hydropower structures," in Comprehensive Renewable Energy, A. Sayigh, Ed., Elsevier, Oxford, UK, pp. 377-403, 2012.

[47] Z. Li and C. Leung, Structural Renovation in Concrete, CRC Press, Boca Raton, FL, USA, 2009.

[48] R. Polat, "The effect of antifreeze additives on fresh concrete subjected to freezing and thawing cycles," Cold Regions Science and Technology, vol. 127, pp. 10-17, 2016.

[49] S. Njdot, Specifications for Road and Bridge Works, Department of Transportation, Ewing Township, NJ, USA, 2019.

[50] MnDOT, Standard Specifications for Construction, Minnesota Department of Transportation, Saint Paul, MN, USA, 2018.

[51] T. J. Van Dam, K. Peterson, L. Sutter et al., NCHRP Report 540: Guidelines for Early-Opening-To-Traffic Portland Cement Concrete for Pavement Rehabilitation, N. Buch, Ed., Vol. 38, The National Academies Press, Washington, DC, USA, 2005.

[52] M. Pigeon and R. Pleau, Durability of Concrete in Cold Climates, Taylor \& Francis, Oxford, UK, 2010.

[53] ACI Committee 201, ACI 201.2R-16 Guide to Durable Concrete, ACI, Farmington Hills, MI, USA, 2016.

[54] IFSTTAR, Recommendations for preventing disorders due to delayed ettringite formation, in Technical Guide, IFSTTAR, Marne-la-Vallée, France, 2018.

[55] CDOT, Standard Specifications for Road and Bridge Construction, Colorado Department of Transportation, Denver, CO, USA, 2019.

[56] C. J. Larosche, "Types and causes of cracking in concrete structures," in Failure, Distress and Repair of Concrete Structures, N. Delatte, Ed., Woodhead Publishing, Sawston, Cambridge, UK, pp. 57-83, 2009.

[57] B. Godart and L. Divet, "Lessons learned from structures damaged by delayed ettringite formation and the French prevention strategy, in Forensic Engineering: Informing the Future with Lessons from the Past," in Proceedings of the Fifth International Conference on Forensic Engineering Organised by the Institution of Civil Engineers and Held in London, J. Carpenter, Ed., pp. 387-400pp. 387-, London, UK, April 2013.

[58] E. V. Dave, J. Dailey, and E. Musselman, "Evaluation of Concrete and Mortars for Partial Depth Repairs," MnDOT 2014-41, p. 233, Minnesota Department of Transportation, Minnesota, MN, USA, 2014.

[59] TxDOT, Concrete Repair Materials- Material Producer List, TxDOT, Austin, TX, USA, 2018.

[60] D. Cusson, "Durability of repaired concrete structures," in Failure, Distress and Repair of Concrete Structures, N. Delatte, Ed., Woodhead Publishing, Sawston, Cambridge, UK, pp. 296-321, 2009.

[61] T. Zych, "Test methods of concrete resistance to chloride ingress," Tech. Trans. Civ. Eng.vol. 6, pp. 117-139, 2014. 
[62] P. C. Taylor and G. F. Voigt, Integrated Materials and Construction Practices for Concrete Pavement: A State-OfThe-Practice Manual, p. 355, National Concrete Pavement Technology Center/Center for Transportation Research and Education, Ames, IA, USA, 2007.

[63] M. Yang, M. Abdelrahman, S. Ahmari, and H. Alanazi, "Survey and Literature Review of Fast-Track PCC Pavement Repair Processes and Materials," North Dakota Department of Transportation, Bismarck, ND, USA, NDSU-2013-02, 2013.

[64] American Society for Testing and Materials, ASTM C1202 Standard Test Method for Electrical Indication of Concrete's Ability to Resist Chloride Ion Penetration, ASTM, West Conshohocken, PA, USA, 2012.

[65] A. E. Sommerville, "Selection of high performance repair materials for pavements and bridge decks," in Civil EngineeringCleveland State University, Ohio, OH, USA, 2014.

[66] TxDOT, Concrete Repair Manual, Texas Department of Transportation, Austin, TX, USA, 2019.

[67] A. Arora, B. Singh, and P. Kaur, "Novel material i.e. magnesium phosphate cement (MPC) as repairing material in roads and buildings," Materials Today Proceedings, vol. 17, pp. 70-76, 2019.

[68] P. V. Ram, K. D. Smith, A. Shah, O. Jan, V. D. Tom, and S. Larry, Non-Cementitious Repair Materials Study, Wisconsin Department of Transportation, Madison, WI, USA, 2019.

[69] M. Ramsey, D. A. Scott, C. A. Weiss, and J. S. Tingle, "Development of Magnesium Phosphate Cement (MPC) concrete Mixture Proportioning for Airfield Pavements: Laboratory and Field Validation MPC Test Report." Engineer Research and Development Center, Vicksburg, MS, USA, ERDC/GSL TR-20-4, 2020.

[70] American Society for Testing and Materials, ASTM C928/ C928M Standard Specification for Packaged, Dry, RapidHardening Cementitious Materials for Concrete Repairs, ASTM, West Conshohocken, PA, USA, 2020.

[71] Q. B. Yang, "Durability and applications of magnesium phosphate material for rapid repair of pavements," in Advanced Pavement Research, B. Tian and K. Niu, Eds., pp. 81-89, Trans Tech Publications Ltd, Stafa-Zurich, Switzerland, 2014.

[72] F. Qiao, C. K. Chau, and Z. Li, "Property evaluation of magnesium phosphate cement mortar as patch repair material," Construction and Building Materials, vol. 24, no. 5, pp. 695-700, 2010.

[73] J. W. Park, K. H. Kim, and K. Y. Ann, "Fundamental properties of magnesium phosphate cement mortar for rapid repair of concrete," Advances in Materials Science and Engineering, vol. 2016, Article ID 7179403, 7 pages, 2016.

[74] J. Wu, Z. Lai, Q. Deng, and M. Liu, "Effects of various curing conditions on volume stability of magnesium phosphate cement," Advances in Materials Science and Engineering, vol. 2021, Article ID 6652363, 12 pages, 2021.

[75] M. Ramsey, S. Dylan, W. Charles, and T. Jeb, "Effects of Boric Acid and Water Content on Fundamental Properties of Proprietary Magnesium Phosphate Cement (MPC) Products," Engineer Research and Development Center, Vicksburg, MS, USA, ERDC TR-20-12-DRAFT, 2020.

[76] L. Jia, F. Zhao, J. Guo, and K. Yao, "Properties and reaction mechanisms of magnesium phosphate cement mixed with ferroaluminate cement," Materials, vol. 12, no. 16, 2019.

[77] X. Zhang, G. Li, M. Niu, and Z. Song, "Effect of calcium aluminate cement on water resistance and high-temperature resistance of magnesium-potassium phosphate cement," Construction and Building Materials, vol. 175, pp. 768-776, 2018.

[78] G. Zhang, G. Li, and T. He, "Effects of sulphoaluminate cement on the strength and water stability of magnesium potassium phosphate cement," Construction and Building Materials, vol. 132, pp. 335-342, 2017.

[79] L. Chong, C. Shi, J. Yang, and H. Jia, "Effect of limestone powder on the water stability of magnesium phosphate cement-based materials," Construction and Building Materials, vol. 148, pp. 590-598, 2017.

[80] R. C. Barborak, Calcium Aluminate Cement Concrete ( Class CAC Concrete) TxDOT Special Specification SS-4491 Tip Sheet, p. 6, TXDOT, Austin, TX, USA, 2011.

[81] M. C. G. Juenger, F. Winnefeld, J. L. Provis, and J. H. Ideker, "Advances in alternative cementitious binders," Cement and Concrete Research, vol. 41, no. 12, pp. 1232-1243, 2011.

[82] British Standards Institution, BS EN 14647:2005 Calcium Aluminate Cement - Composition, Specifications and Conformity Criteria, BSI, London, UK, 2005.

[83] J. Ideker, C. Gosselin, and R. Barborak, "An alternative repair material," Concrete International, vol. 35, no. 4, 2013.

[84] TxDOT, TxDOT SS-4491 (Class CAC Concrete) Important Items for Construction and Inspection, TxDOT, Austin, TX, USA, 2011.

[85] J. Péra and J. Ambroise, "New applications of calcium sulfoaluminate cement," Cement and Concrete Research, vol. 34, no. 4, pp. 671-676, 2004.

[86] D. Knöfel and J. F. Wang, "Properties of three newly developed quick cements," Cement and Concrete Research, vol. 24, no. 5, pp. 801-812, 1994.

[87] R. J. Sun, Z. Ge, W. Li, H. F. Zhou, and D. W. Huang, "Experimental research of the rapid set cement concrete for rapid repair of concrete pavements," in Advanced Materials Research, 634-638, in Advances in Chemical, Material and Metallurgical Engineering, Pts 1-5, J. M. Zeng, H. X. Zhu, and J. Y. Kong, Eds., Trans Tech Publications Ltd, Stafa-Zurich, Switzerland, pp. 2697-2701, 2013.

[88] J. Ambroise and J. Péra, "Use of calcium sulfoaluminate cement to improve strength of mortars at low temperature, in Concrete Repair, Rehabilitation and Retrofitting II," in Proceedings of the Second International Conference on Concrete Repair, Rehabilitation and Retrofitting, ICCRRR-2, pp. 325-328, CRC Press, Cape Town, South Africa, November 2008.

[89] K. D. Bruyn, E. Bescher, C. Ramseyer, S. Hong, and T. H. K. Kang, "Pore structure of calcium sulfoaluminate paste and durability of concrete in freeze-thaw environment," International Journal of Concrete Structures and Materials, vol. 11, no. 1, pp. 59-68, 2017.

[90] F. P. Glasser and L. Zhang, "High-performance cement matrices based on calcium sulfoaluminate-belite compositions," Cement and Concrete Research, vol. 31, no. 12, pp. 1881-1886, 2001.

[91] C. W. Hargis, B. Lothenbach, C. J. Müller, and F. Winnefeld, "Carbonation of calcium sulfoaluminate mortars," Cement and Concrete Composites, vol. 80, pp. 123-134, 2017.

[92] V. Afroughsabet, L. Biolzi, P. J. M. Monteiro, and M. M. Gastaldi, "Investigation of the mechanical and durability properties of sustainable high performance concrete based on calcium sulfoaluminate cement," Journal of Building Engineering, vol. 43, Article ID 102656, 2021.

[93] D. Kalogridis, G. C. Kostogloudis, C. Ftikos, and C. Malami, "A quantitative study of the influence of non-expansive 
sulfoaluminate cement on the corrosion of steel reinforcement," Cement and Concrete Research, vol. 30, no. 11, pp. 1731-1740, 2000.

[94] G. Jen, N. Stompinis, and R. Jones, "Chloride ingress in a belite-calcium sulfoaluminate cement matrix," Cement and Concrete Research, vol. 98, pp. 130-135, 2017.

[95] M. Miller and R. T. Limited, Polymers in Cementitious Materials, Rapra Technology Limited, Shrewsbury, UK, 2005.

[96] N. Delatte, R. A. Miller, M. Asghar et al., Evaluation of High Performance Pavement and Bridge Deck Wearing Surface Repair Materials, Ohio Department of Transportation, Columbus, OH, USA, 2016.

[97] J. V. Brien and K. C. Mahboub, "Influence of polymer type on adhesion performance of a blended cement mortar," International Journal of Adhesion and Adhesives, vol. 43, pp. 7-13, 2013.

[98] S. Zhang, G. Z. Li, C. Ning, and H. Y. Yuan, "Performance properties of polymer modified cement grouts for repair and rehabilitation of concrete pavement," in Advances in Superalloys, Pts 1 and 2, S. Jiao, Z. Y. Jiang, and J. L. Bu, Eds., Trans Tech Publications Ltd:, Stafa-Zurich, Switzerland, pp. 345-348, 2011.

[99] T. L. Weng, W. T. Lin, and C. H. Li, "Properties evaluation of repair mortars containing EVA and VA/VeoVa polymer powders," Polymers and Polymer Composites, vol. 25, no. 1, pp. 77-86, 2017.

[100] N. Su, L. Lou, A. Amirkhanian, S. N. Amirkhanian, and F. Xiao, "Assessment of effective patching material for concrete bridge deck -A review," Construction and Building Materials, vol. 293, Article ID 123520, 2021.

[101] J. Mirza, M. S. Mirza, and R. Lapointe, "Laboratory and field performance of polymer-modified cement-based repair mortars in cold climates," Construction and Building Materials, vol. 16, no. 6, pp. 365-374, 2002.

[102] B. J. Lee and Y. Y. Kim, "Durability of latex modified concrete mixed with a shrinkage reducing agent for bridge deck pavement," International Journal of Concrete Structures and Materials, vol. 12, no. 1, 2018.

[103] S. H. Kosmatka and M. L. Wilson, Design and Control of Concrete Mixtures the Guide to Applications, Methods, and Materials, Portland Cement Association, Skokie, IL, USA, 15 edition, 2011.

[104] British Standards Institution, BS EN 197-1:2011 Cement - Part 1: Composition, Specifications and Conformity Criteria for Common Cements, BSI, London, UK, 2011.

[105] American Society for Testing and Materials, ASTM C 150/C $150 M$ - 20 Standard Specification for Portland Cement, ASTM, West Conshohocken, PA, USA, 2020.

[106] N. T. Todd, Assessing Risk Reduction of High Early Strength Concrete Mixtures, Purdue University, West Lafayette, IN, USA, 2015

[107] N. Ghafoori, M. Najimi, and M. Maler, High-Early-Strength High-Performance Concrete for Rapid Pavement Repair, Nevada Department of Transportation, Reno, NV, USA, 2017.

[108] N. Ghafoori, H. Diawara, and S. Beasley, "Resistance to external sodium sulfate attack for early-opening-to-traffic Portland cement concrete," Cement and Concrete Composites, vol. 30, no. 5, pp. 444-454, 2008.

[109] T. B. Min, I. S. Cho, W. J. Park, H. K. Choi, and H. S. Lee, "Experimental study on the development of compressive strength of early concrete age using calcium-based hardening accelerator and high early strength cement," Construction and Building Materials, vol. 64, pp. 208-214, 2014.

[110] H. T. Yu, J. Mallela, and M. I. Darter, Highway Concrete Technology Pavement Development and Testing: Volume IV Evaluation of Strategic Highway Research Program (SHRP) C-206 Test Sites (Early Opening of Full-Depth Pavement Repairs), Federal Highway Administration, McLean, VA, USA, 2006.

[111] R. Myrdal, Accelerating Admixtures for concrete, p. 35, SINTEF Building and Infrastructure, Trondheim, Norway, 2007.

[112] P. C. Aïtcin, "19 - accelerators," in Science and Technology of Concrete Admixtures, P. C. Aïtcin and R. J. Flatt, Eds., pp. 405-413, Woodhead Publishing, Cambridge, UK, 2016.

[113] N. Buch, T. J. V. Dam, K. Peterson, and L. Sutter, "Evaluation of high-early strength PCC mixtures used in full depth repairs," Construction and Building Materials, vol. 22, no. 3, pp. 162-174, 2008.

[114] N. Ghafoori and M. W. Tays, "Abrasion resistance of earlyopening-to-traffic portland cement concrete pavements," Journal of Materials in Civil Engineering, vol. 19, no. 11, pp. 925-935, 2007.

[115] D. C. Teychenné, R. E. Franklin, and H. C. Erntroy, Design of normal concrete Mixes, brcPress, Bracknell, UK, 1997.

[116] ACI Committee 211, ACI 211.1-91: Standard Practice for Selecting Proportions for Normal, Heavyweight, and Mass Concrete (Reapproved 2009), ACI, Farmington Hills, MI, USA, 2002.

[117] ACI, ACI CT-18 ACI Concrete Terminology, ACI, Farmington Hills, MI, USA, 2018.

[118] MDOT, Mississippi Standard Specifications for Road and. Bridge Construction, Mississippi Department of Transportation, Jackson, WY, USA, 2017.

[119] G. F. Peng, Q. Ma, H.-M. Hu, R. Gao, Q. F. Yao, and Y. F. Liu, "The effects of air entrainment and pozzolans on frost resistance of 50-60MPa grade concrete," Construction and Building Materials, vol. 21, no. 5, pp. 1034-1039, 2007.

[120] G. Peng, D. Niu, X. Hu, B. Pan, and S. Zhong, "Experimental study of the interfacial bond strength between cementitious grout and normal concrete substrate," Construction and Building Materials, vol. 273, Article ID 122057, 2021.

[121] S. H. A. Sabah, M. H. Hassan, N. B. Muhamad, and M. A. J. Megat, "Bond strength of the interface between normal concrete substrate and GUSMRC repair material overlay," Construction and Building Materials, vol. 216, pp. 261-271, 2019.

[122] P. Richard and M. H. Cheyrezy, Reactive Powder Concretes with High Ductility and 200 - 800 Mpa Compressive Strength, ACI Symposium Publication, vol. 144, 1994.

[123] D. Zhang, Y. Liu, and K. H. Tan, "Spalling resistance and mechanical properties of strain-hardening ultra-high performance concrete at elevated temperature," Construction and Building Materials, vol. 266, Article ID 120961, 2021.

[124] Afnor, N. F. P18-710 National Addition to Eurocode 2 - Design of concrete Structures: Specific Rules for Ultra-high Performance Fibre-Reinforced Concrete (UHPFRC), AFNOR:, La PlaineSaint-Denis, France, 2016.

[125] K. Wille, A. E. Naaman, and G. J. M. Parra, "Ultra-high performance concrete with compressive strength exceeding $150 \mathrm{MPa}$ ( $22 \mathrm{ksi}$ ): a simpler way," ACI Materials Journal, vol. 108, no. 1, pp. 46-54, 2011.

[126] H. Yazııı, M. Y. Yardımcı, H. Yiğiter, S. Aydın, and S. Türkel, "Mechanical properties of reactive powder concrete containing high volumes of ground granulated blast furnace 
slag," Cement and Concrete Composites, vol. 32, pp. 639-648, 2010.

[127] P. P. Li, H. J. H. Brouwers, W. Chen, and Q. Yu, "Optimization and characterization of high-volume limestone powder in sustainable ultra-high performance concrete," Construction and Building Materials, vol. 242, Article ID 118112, 2020.

[128] M. A. Bahedh and M. S. Jaafar, "Ultra high-performance concrete utilizing fly ash as cement replacement under autoclaving technique," Case Studies in Construction Materials, vol. 9, Article ID e00202, 2018.

[129] I. Ferdosian, A. Camões, and M. Ribeiro, "High-volume fly ash paste for developing ultra-high performance concrete (UHPC)," Ciência \& Tecnologia dos Materiais, vol. 29, no. 1, pp. e157-e161, 2017.

[130] M. G. Lee, Y. C. Wang, and C. T. Chiu, "A preliminary study of reactive powder concrete as a new repair material," Construction and Building Materials, vol. 21, no. 1, pp. 182-189, 2007.

[131] S. L. Yang, S. G. Millard, M. N. Soutsos, S. J. Barnett, and T. T. Le, "Influence of aggregate and curing regime on the mechanical properties of ultra-high performance fibre reinforced concrete (UHPFRC)," Construction and Building Materials, vol. 23, no. 6, pp. 2291-2298, 2009.

[132] R. Yu, P. Spiesz, and H. J. H. Brouwers, "Development of an eco-friendly Ultra-High Performance Concrete (UHPC) with efficient cement and mineral admixtures uses," Cement and Concrete Composites, vol. 55, pp. 383-394, 2015.

[133] M. Gesoglu, E. Güneyisi, A. H. Nahhab, and H. Yazıcı, "The effect of aggregates with high gypsum content on the performance of ultra-high strength concretes and Portland cement mortars," Construction and Building Materials, vol. 110, pp. 346-354, 2016.

[134] Y. Sun, R. Yu, S. Wang et al., "Development of a novel ecoefficient LC2 conceptual cement based ultra-high performance concrete (UHPC) incorporating limestone powder and calcined clay tailings: design and performances," Journal of Cleaner Production, vol. 315, Article ID 128236, 2021.

[135] R. Bornemann and S. Faber, "UHPC with steel- and noncorroding high strength polymer fibres under static and cyclic loading," in Proceedings of the International Symposium on Ultra-high Performance Concrete, University of Kassel, Kassel, Germany, September 2004.

[136] J. Grünberg and C. Ertel, "A triaxial fatigue model of ultrahigh performance concrete (UHPC)," in Proceedings of the 3rd International Symposium on UHPC and Nanotechnology for High Performance Construction Materials, University of Kassel, Kassel, Germany, March 2012.

[137] E. S. Lappa and C. R. Braam, "Static and fatigue bending tests of UHPC," in Proceedings of the International Symposium on Ultra-high Performance Concrete, University of Kassel, Kassel, Germany, September 2004.

[138] L. Sui, Q. Zhong, K. Yu, F. Xing, P. Li, and Y. Zhou, "Flexural Fatigue Properties of Ultra-high Performance Engineered Cementitious Composites (UHP-ECC)," Polymers, 2018, vol. 10, no. 8, 2018.

[139] S. H. Yeo, Mechanical Properties and Durability of Reactive Powder Concrete with Polyvinyl Alcohol FibreCivil Engineering Department, University of Malaya, Kuala Lumpur, Malaysia, 2013.

[140] T. Ono, "Application of ultra-high-strength fiber-reinforced concrete for irrigation channel repair works," in Designing and Building with UHPFRC, pp. 541-552, Wiley, NJ, USA, 2011.
[141] Z. B. Haber, J. F. Munoz, I. D. L. Varga, and B. A. Graybeal, "Bond characterization of UHPC overlays for concrete bridge decks: laboratory and field testing," Construction and Building Materials, vol. 190, pp. 1056-1068, 2018.

[142] L. Yang, C. Shi, and Z. Wu, "Mitigation techniques for autogenous shrinkage of ultra-high-performance concrete - a review," Composites Part B: Engineering, vol. 178, Article ID 107456, 2019.

[143] L. Caixia, S. Zhilin, Y. Liqi, and Z. Guorong, "Study on autogenous shrinkage characteristic and mechanism of ultrahigh performance cementitous composite," IOP Conference Series: Materials Science and Engineering, vol. 324, Article ID 12037, 2018.

[144] K. Liu, R. Yu, Z. Shui et al., "Optimization of autogenous shrinkage and microstructure for Ultra-High Performance Concrete (UHPC) based on appropriate application of porous pumice," Construction and Building Materials, vol. 214, pp. 369-381, 2019.

[145] J. Li, Z. Wu, C. Shi, Q. Yuan, and Z. Zhang, "Durability of ultra-high performance concrete - a review," Construction and Building Materials, vol. 255, Article ID 119296, 2020.

[146] M. Thomas, B. Green, E. O’Neal, V. Perry, S. Hayman, and A. Hossack, "Marine performance of UHPC at treat island," in Proceedings of the Third International Symposium on UHPC and Nanotechnology for High Performance Construction Materials, University of Kassel, Kassel, Germany, March 2012.

[147] M. An, Y. Wang, and Z. Yu, "Damage mechanisms of ultrahigh-performance concrete under freeze-thaw cycling in salt solution considering the effect of rehydration," Construction and Building Materials, vol. 198, pp. 546-552, 2019.

[148] Z. Lu, Z. G. Feng, D. Yao, X. Li, and H. Ji, "Freeze-thaw resistance of Ultra-High performance concrete: dependence on concrete composition," Construction and Building Materials, vol. 293, Article ID 123523, 2021.

[149] B. A. Graybeal, "Material Property Characterization of Ultrahigh Performance concrete," Federal Highway Administration, Office of Research, Development and Technology, Turner-Fairbank Highway Research Center, McLean, VA, USA, FHWA-HRT-06-103, 2006.

[150] J. S. J. V. Deventer, J. L. Provis, and P. Duxson, “Technical and commercial progress in the adoption of geopolymer cement," Minerals Engineering, vol. 29, pp. 89-104, 2012.

[151] A. M. Rashad and M. Gharieb, "Solving the perpetual problem of imperative use heat curing for fly ash geopolymer cement by using sugar beet waste," Construction and Building Materials, vol. 307, Article ID 124902, 2021.

[152] M. Gharieb, Y. A. Mosleh, and A. M. Rashad, "Properties and corrosion behaviour of applicable binary and ternary geopolymer blends," International Journal of Sustainable Engineering, vol. 14, no. 5, pp. 1068-1080, 2021.

[153] H. Zhu, G. Liang, H. Li et al., "Insights to the sulfate resistance and microstructures of alkali-activated metakaolin/ slag pastes," Applied Clay Science, vol. 202, Article ID 105968, 2021.

[154] B. S. Mohammed, S. Haruna, M. M. A. Wahab, M. S. Liew, and A. Haruna, "Mechanical and microstructural properties of high calcium fly ash one-part geopolymer cement made with granular activator," Heliyon, vol. 5, no. 9, Article ID e02255, 2019.

[155] J. Zhang, G. Pan, and Y. Yan, "Early hydration, mechanical strength and drying shrinkage of low-carbon alkali-activated Ti-extracted residues-fly ash cement and mortars," 
Construction and Building Materials, vol. 293, Article ID 123517, 2021.

[156] M. S. Rezende, W. J. D. Santos, and P. H. R. Borges, "On the development of MK/BFS alkali-activated materials as repair mortars: performance under free and restrained shrinkage tests," Construction and Building Materials, vol. 275, Article ID 122109, 2021.

[157] S. Asayesh, A. A. J. Shirzadi, H. Ziari, and B. Mehri, "Evaluating fresh state, hardened State, thermal expansion and bond properties of geopolymers for the repairing of concrete pavements under restrained conditions," Construction and Building Materials, vol. 292, Article ID 123398, 2021.

[158] H. Y. Zhang, G. H. Qiu, V. Kodur, and Z. S. Yuan, "Spalling behavior of metakaolin-fly ash based geopolymer concrete under elevated temperature exposure," Cement and Concrete Composites, vol. 106, Article ID 103483, 2020.

[159] A. M. Rashad, S. A. Khafaga, and M. Gharieb, "Valorization of fly ash as an additive for electric arc furnace slag geopolymer cement," Construction and Building Materials, vol. 294, Article ID 123570, 2021.

[160] C. O. Plamondon and G. Habert, "Life cycle assessment (LCA) of alkali-activated cements and concretes," in Handbook of Alkali-Activated Cements, Mortars and Concretes, F. Pacheco-Torgal, J. A. Labrincha, C. Leonelli, A. Palomo, and P. Chindaprasirt, Eds., Woodhead Publishing, Oxford, UK, pp. 663-686, 2015.

[161] B. C. McLellan, R. P. Williams, J. Lay, A. V. Riessen, and G. D. Cordera, "Costs and carbon emissions for geopolymer pastes in comparison to ordinary portland cement," Journal of Cleaner Production, vol. 19, no. 9-10, pp. 1080-1090, 2011.

[162] A. M. Rashad, A. S. Ouda, and D. M. Sadek, "Behavior of alkali-activated metakaolin pastes blended with quartz powder exposed to seawater attack," Journal of Materials in Civil Engineering, vol. 30, no. 8, Article ID 4018159, 2018.

[163] K. Ramujee and M. Potharaju, "Abrasion resistance of geopolymer composites," Procedia Materials Science, vol. 6, pp. 1961-1966, 2014.

[164] D. K. Ballekere and S. Peethamparan, "Quantification of Drying Shrinkage in Alkali Activated Slag Mortars and Validating the Efficiency of Various Shrinkage Mitigation Methods," in Proceedings of the Transportation Research Board Ninety Sixth Annual Meeting, Washington, DC, USA, January 2017.

[165] C. A. Duran, C. Bilim, Ö. Çelikc, and O. Karahan, "Influence of activator on the strength and drying shrinkage of alkaliactivated slag mortar," Construction and Building Materials, vol. 23, no. 1, pp. 548-555, 2009.

[166] M. Palacios and F. Puertas, "Effect of shrinkage-reducing admixtures on the properties of alkali-activated slag mortars and pastes," Cement and Concrete Research, vol. 37, no. 5, pp. 691-702, 2007.

[167] T. Bakharev, J. G. Sanjayan, and Y. B. Cheng, "Effect of admixtures on properties of alkali-activated slag concrete," Cement and Concrete Research, vol. 30, no. 9, pp. 1367-1374, 2000.

[168] D. K. Ballekere, S. Peethamparan, and M. Ngami, “Autogenous shrinkage of alkali activated slag mortars: basic mechanisms and mitigation methods," Cement and Concrete Research, vol. 109, pp. 1-9, 2018.

[169] G. F. Huseien and K. W. Shah, "Performance evaluation of alkali-activated mortars containing industrial wastes as surface repair materials," Journal of Building Engineering, vol. 30, Article ID 101234, 2020.
[170] R. Zhao, Y. Yuan, Z. Cheng et al., "Freeze-thaw resistance of Class F fly ash-based geopolymer concrete," Construction and Building Materials, vol. 222, pp. 474-483, 2019. 